changes herein described might be a consequence of 5-hydroxytryptamine release, due to the toxin.

H. RAŠKoví

J. VANĚČEK

Department of Pharmacology,

Faculty of Pediatrics,

Charles University,

Prague.

Dec. 20

${ }^{1}$ Feldberg, W., and Sherwood, S. L., $J$. Physiol., 120, $3 P$ (1953).

2 Rašková, H., Rałka, K., and Sormová, Z., Cas. lék. ées, 89, 1248 $(1950)$.

${ }^{3}$ Feldberg, w., and Sherwood, S. L., J. Physiol., 123, 148 (1954).

4 Gaddum, J. H. and Vogt, M., Brit. J. Pharmacol, 11, 175 (1956).

5 Fink, M. A., Proc. Soc. Exp. Biol. Med., 92, 673 (1956).

'Twarog, B. M., and Page, I. H., Amer. J. Physiol., 175, 157 (1953).

'Amin, A. H., Crawford, T. B. B., and Gaddum, J. H., J. Physiol. 128. 596 (1954).

\section{Immunoelectrophoretic Evidence for the Presence of Two Precipitating Antibodies in Serum following Infection with the Virus of Foot-and-Mouth Disease}

THE results of the application of the technique of precipitation in agar gel to a study of the antigenic composition of the virus of foot-and-mouth disease have been reported by Brown and Crick ${ }^{1,2}$. It was tentatively concluded that two antibodies are present in the serum of guinea pigs and cattle convalescent from the disease on the evidence that $(a)$ two precipitin lines were obtained when suspensions of the virus were diffused towards homotypic serum and (b) formation of one of the precipitin lines could be prevented if the immune serum was mixed with excess of the $7 \mathrm{~m} \mu$ component of the virus before test. It was considered that the immunoelectrophoretic technique of Grabar and Williams ${ }^{3}$, in which the protein mixture under examination is first separated in an electric field before analysis by diffusion, might provide further evidence on this point.

Hyperimmune guinea pig serum was first separated by electrophoresis in 1.5 per cent agar, under the conditions described by Grabar and Williams $(0.05 M$ sodium veronal buffer, $p \mathrm{H} 8.2 ; 4$ volts/cm.). Following electrophoresis, channels parallel to the direction of migration of the serum proteins were cut from the agar and filled with preparations of the virus or fractions separated from the virus. Two precipitin lines were formed between the separated serum and the channel containing the total virus pre. paration, showing quite clearly that separation of the two precipitating antibodies had occurred during electrophoresis (Fig. 1). If, instead of the total virus, a preparation of the $7 m \mu$ component of the virus was placed in the channel, only one of the precipitin lines was then obtained. Similarly, a mixture of a virus preparation of the same immunological type and a heterotypic immune serum placed in the channel produced the other precipitin line. Brown and Crick ${ }^{2}$ have shown that this mixture yielded a precipitin line identical
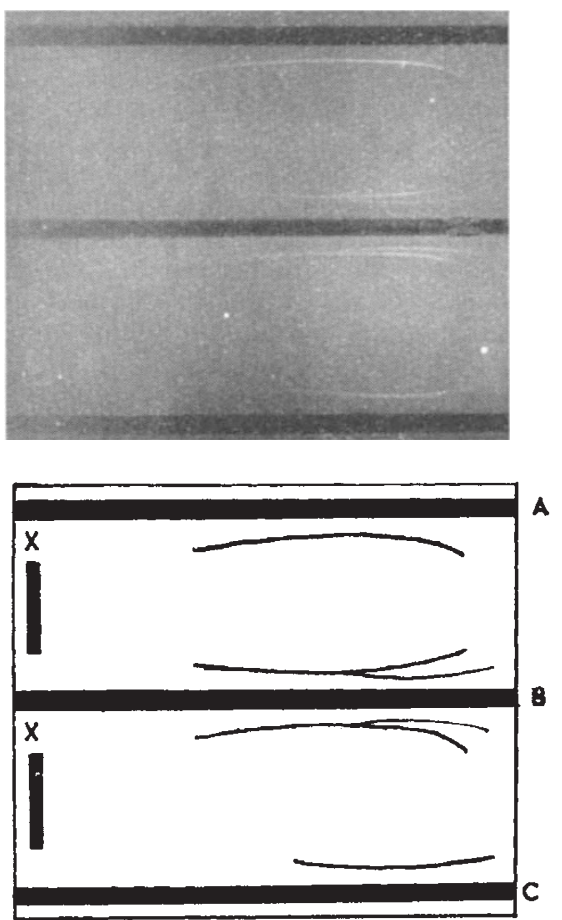

Fig. 1. Reaction of fractions of the virus of foot-and-mouth disease with homotypic immune guinea pig serum separated by electrophoresis in agar. The section of the plate on the negative side of the starting point $(X)$ is shown. Channel $A$ containg the $7 \mathrm{~m} \mu$ component of the virus, channel $B$ total virus suspension and channel $C$ a mixture of total virus with a heterotypic antiserum

with that produced by the $20 \mathrm{~m} \mu$ component when it was diffused towards homotypic serum.

Additional evidence that separation of the two antibodies occurs during electrophoresis was obtained by testing sections of the agar along which the serum proteins had moved. These sections were placed in cups eut in an agar gel, and their contents allowed to diffuse towards a virus suspension. The precipitin line pattern obtained is shown diagrammatically in Fig. 2, from which it can be seen that, although most
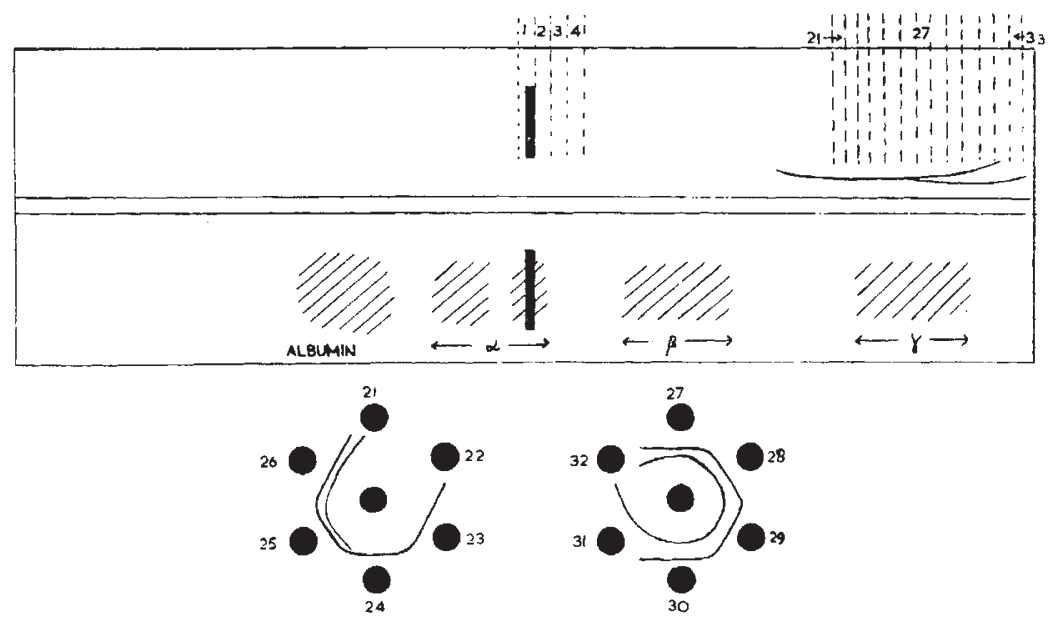
Fig. 2. Flectrophoresis of guinea pig antiserum followed by diffusion against virus of the
same type. Diffusion was carried out as described by Grabar and Williams and by removing sections of the agar and testing them in the hexagonal arrangement shown. The numbers of the cups correspond to the sections removed from the agar. The positions of the proteins separated during electrophoresis are shown in the lower lane (stained by amidoschwarz) 
of the sections in the $\gamma$-globulin region gave two precipitin lines, only one line was obtained at each end of the precipitin range, corresponding to the line produced by the $7 \mathrm{~m} \mu$ component (for the sections nearer to the starting point) and the $20 \mathrm{~m} \mu$ component (for the sections nearer to the cathode). It will be noticed that the distance between the precipitin lines was not constant, indicating that the relative concentration of the two antibodies was different in each section. The corresponding precipitin line pattern obtained by the method of Grabar and Williams is shown alongside.

Evidence is also being accumulated which shows that stepwise precipitation of immune serum with increasing concentrations. of ammonium sulphate yields fractions which contain the two precipitating antibodies in proportions different from that in which they are present in the original serum. There can be little doubt, therefore, that the two precipitin lines obtained when suspensions of the virus of foot. and-mouth disease are diffused towards homotypic immune serum are due to the presence of distinct antibodies in the serum.

Research Institute

\section{F. BRowN}

(Animal Virus Diseases),

Pirbright, Surrey. Feb. 7.

${ }^{1}$ Brown, F., and Crick, J., Nature, 179, 316 (195i).

${ }^{2}$ Brown, F., and Crick, J., Virology, 5, 133 (1958).

${ }^{3}$ Grabar, P., and Williams, C. A., Biochim. Biophys. Acta, 10, 193 (1953).

\section{A Theory of Oxidative Phosphorylation}

Evidence has been put forward that naphthoquinone derivatives take part in the phosphorylation of adenosine diphosphate to adenosine triphosphate by animal tissues ${ }^{1}$, chloroplasts ${ }^{2}$ and bacteria ${ }^{3}$. A similar role in phosphorylation by animal tissues has been proposed for $\alpha$-tocopherylquinone ${ }^{4}$. It is therefore possible to formulate an earlier suggestion ${ }^{5}$ in more general terms, as follows :

(I)

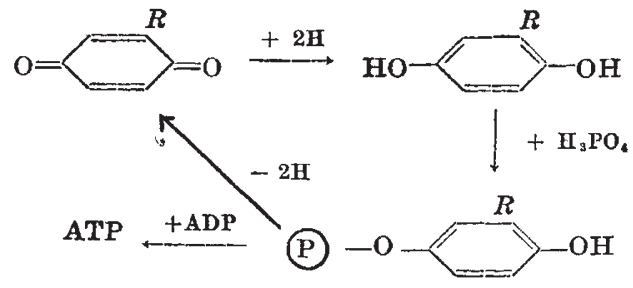

A substituted quinone (I) is reduced to the hydroquinone (II) and phosphorylated (III). Regarded as an attack by adenosine diphosphate ${ }^{\ominus}$ the reaction. (III) $\rightarrow($ I) can be written :

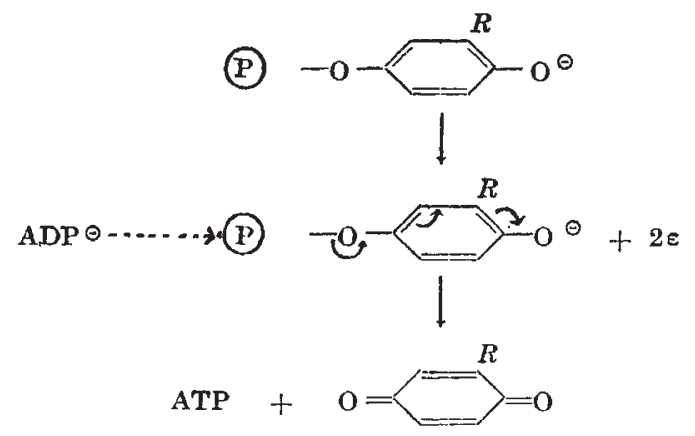

If this scheme is correct, a function of ferric ions in (for example) cytochrome $c$ may be to trap electrons liberated by the hydroquinone derivative during its oxidation. A two-stage process, involving a semiquinone anion, is perhaps more likely than not :

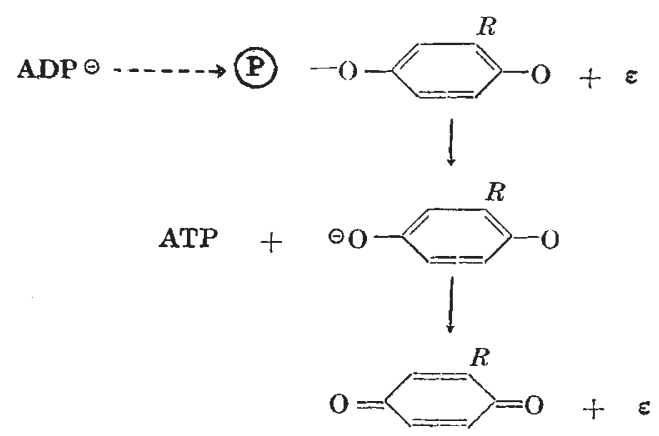

There is a formal similarity between the removal of electrons from compounds of type (III) by oxidizing agents and the activation of phosphoramidic esters by protonation; these esters have been shown ${ }^{8}$ to phosphorylate adenosine diphosphate to the triphosphate.

Although vitamin $\mathbf{K}_{1}$ could affect metabolism in more than one way, chemical considerations would seem to point to coupled phosphorylation as the first choice.

Department of Biochemistry,

K. HARRISON

University of Cambridge. Feb. 15.

${ }^{2}$ Martius, C., Biochem. Z., 327, 407 (1956).

${ }^{2}$ Arnon, D. I., Allen, M. B., and Whatley, F. R., Biochim. Biophys. Acta, 20, 449 (1956).

${ }^{3}$ Brodie, A. F., Weber, M. M., and Gray, C. T., Biochim. Biophys. Acta, 25, 448 (1957).

4 Bouman. J., and Slater, E. C., Biochim. Biophys. Acta, 26, 624 (1957).

${ }^{5}$ Wessels, J. S. C., Rec. Trav. chim. Pays-Bas, 73, 529 (1954). "Clark, v. M., Kirby, G. W., and Todd, A. R., J. Chem. 'Soc.,
1497 (1957).

\section{Constitution of Verdohæm}

VERDOH which the conversion of hæmin into biliverdin wes first achieved ${ }^{1}$. In a recent paper ${ }^{2}$, Rackow discusses its structure. He refers only to my first paper ${ }^{1}$, but not to later papers ${ }^{3-5}$ in which a modified formula with a ring containing an oxygen atom instead of one carbon atom of the porphyrin ring was suggested on the basis of new evidence. The structure suggested by Rackow is that of a pyridinium salt of an $\alpha$-hydroxyporphyrin-iron complex carrying on its iron atom one molecule of pyridine and one molecule of oxygen bound as in oxyhæmoglobin.

The structure proposed by Rackow cannot be accepted for the following reasons :

(1) It does not account for the liberation of carbon monoxide, which has been demonstrated by Drabkin et al. ${ }^{6}$ to occur during verdohæmochrome formation, not during its conversion into biliverdin. The previous inability to demonstrate this carbon atom was one of the main arguments of the Fischer school in favour of an intact porphyrin ring in verdohæm. Such compounds, of $\alpha$-hydroxyporphyrin-hæm character, are indeed formed during the reaction as precur. sors of verdohæmochrome, and their spectroscopic similarity to verdohæmochrome explains Drabkin's 